Review

\title{
Development of Ecological Strategies for the Recovery of the Main Nitrogen Agricultural Pollutants: A Review on Environmental Sustainability in Agroecosystems
}

\author{
Daniela Losacco ${ }^{1,2}\left(\mathbb{D}\right.$, Valeria Ancona ${ }^{1, *}$, Domenico De Paola ${ }^{3}\left(\mathbb{C}\right.$, Marina Tumolo ${ }^{1,2} \oplus$, Carmine Massarelli ${ }^{1}{ }^{(}$, \\ Angela Gatto ${ }^{1}$ and Vito Felice Uricchio ${ }^{1}$ (D) \\ 1 Water Research Institute-Italian National Research Council (IRSA-CNR), 70132 Bari, Italy; \\ daniela.losacco@ba.irsa.cnr.it (D.L.); marina.tumolo@ba.irsa.cnr.it (M.T.); \\ carmine.massarelli@ba.irsa.cnr.it (C.M.); angela.gatto@ba.irsa.cnr.it (A.G.); vito.uricchio@ba.irsa.cnr.it (V.F.U.) \\ 2 Department of Biology, University of Bari, 70126 Bari, Italy \\ 3 Institute of Biosciences and Bioresources-Italian National Research Council (IBBR-CNR), 70126 Bari, Italy; \\ domenico.depaola@ibbr.cnr.it \\ * Correspondence: ancona@irsa.cnr.it
}

check for updates

Citation: Losacco, D.; Ancona, V.; De Paola, D.; Tumolo, M.; Massarelli, C.; Gatto, A.; Uricchio, V.F. Development of Ecological Strategies for the Recovery of the Main Nitrogen Agricultural Pollutants: A Review on Environmental Sustainability in Agroecosystems. Sustainability 2021, 13, 7163. https://doi.org/10.3390/ su13137163

Academic Editor: Imre J. Holb

Received: 29 April 2021

Accepted: 23 June 2021

Published: 25 June 2021

Publisher's Note: MDPI stays neutral with regard to jurisdictional claims in published maps and institutional affiliations.

Copyright: (c) 2021 by the authors. Licensee MDPI, Basel, Switzerland. This article is an open access article distributed under the terms and conditions of the Creative Commons Attribution (CC BY) license (https:/ / creativecommons.org/licenses/by/ $4.0 /)$.

\begin{abstract}
Nitrogen $(\mathrm{N})$ is a fundamental nutrient for plant growth and for the performance of biological functions. In agroecosystems, nitrogen fertilization is aimed at providing a suitable $\mathrm{N}$ dose for crop growth, avoiding the impoverishment or the improper enrichment of nitrogen compounds in soil. The high application of nitrogen fertilizers is the main cause of the increase in nitrate leaching and loss of the quality of natural resources (groundwater and soil). In the last decades, new sustainable technological approaches have been developed and applied on laboratory and field scales to reduce the impacts of nitrogen pollution on the environmental matrices and to improve the sustainability of agricultural management. This review highlights the results of the implementation of sustainable remediation new strategies to reduce pollution from a main agricultural contaminant (nitrate) and describes the benefits obtained from the use of these solutions in agroecosystems.
\end{abstract}

Keywords: nitrogen fertilization; nitrate leaching; agricultural pollution; sustainable remediation strategies; biochar

\section{Introduction}

Agriculture, in the contemporary era, is characterized by a continuous supply of fertilizers and pesticides to maximize the world yield. In the past, most of the cultivated varieties have been selected and bred under optimal nitrogen conditions. The increased production of synthetic $\mathrm{N}$ fertilizer and the accessibility by farmers caused the increase in the use of nitrogen fertilizers as a guarantee for the agricultural harvest.

From 1930 to 1960, N fertilizer use increased from 1.3 to 10.2 million metric tons (MMt) [1]. In 2014, the global demand for $\mathrm{N}$ fertilizers was $112 \mathrm{MMt}$ [2] and is expected to reach $240 \mathrm{MMt}$ by 2050 [3]. Therefore, there was a concomitant increase in $\mathrm{N}$ losses to the environment, nitrate leaching to groundwater, aquatic eutrophication, ammonia and nitrous oxide emissions, and soil acidification [4,5].

The addition of nitrogen fertilizers has marked effects on the absorption of fertilizer by plants. There are different elements affecting nitrogen compounds uptake and accumulation in vegetable tissues such as environmental and agricultural factors [6]. Deficiency and excess nitrogen in plant species result in more or less evident manifestations depending on the species and climatic conditions (Table 1). 
Table 1. Effects of deficiency and excess of nitrogen fertilizers in plants.

\begin{tabular}{cr}
\hline $\begin{array}{c}\text { Probable Effect of N Deficiency } \\
\text { Photosynthetic rate reductions and Rubisco content decreases } \\
\text { with a low leaf-N content }\end{array}$ & Probable Effect of N Excess \\
\hline $\begin{array}{c}\text { Poor growth of the plants, with reduced dimensions both at the } \\
\text { root level (shallow and ramified roots) and at the level of the } \\
\text { aerial part (small leaves and thin stems) }\end{array}$ & Slow plant development \\
\hline Flowering reduction & Increase in water consumption \\
\hline $\begin{array}{c}\text { Fruit helmet } \\
\text { Reduction of the length of the biological cycle and early } \\
\text { ripening }\end{array}$ & $\begin{array}{c}\text { Reduction of the resistance of the fruits, favoring the breaking } \\
\text { and the phenomena of lodging (for example, in the } \\
\text { autumn-vernini cereals) }\end{array}$ \\
\hline
\end{tabular}

Determination of actual plant consumption of nitrogen $(\mathrm{N})$ is necessary to optimize fertilization efficiency and minimize the contamination of natural resources [7]. At the same times, it is necessary to find new strategies to minimize nitrogen losses, thus avoiding environmental damage.

This review explains the current state of knowledge on the latest ecological strategies for the remediation of groundwater contaminated by agricultural nitrates. In addition, the study aims to assess the application of sustainable technologies in the international scenario in order to provide a useful academic reference in favor of action programmes aimed at sustainable agriculture.

\section{Environmental Pollution by Agricultural Practices}

Nitrogen fertilizers $(\mathrm{N})$ have substantially tripled global food production over the past 50 years [8].

From 1950 to 2019, there was an increase in the global population from 2.5 to 7.7 billion, and it is expected to reach about 9.7 billion by 2050 [9], which poses a major threat to both global food security and environmental sustainability [10].

It has been estimated that, at the end of the 21 st century, about $40 \%$ of the world's population will depend on inputs of fertilizers useful for food production. Therefore, the preparation of accurate fertilization plans in agroecosystems is essential for producing crops capable to meet the increase in food demand.

In agroecosystems, the mass inputs of fertilizers may lead to substantial environmental consequences, such as cascade effects of reactive $\mathrm{N}$, hazardous to human well-being [11,12]. The over-application of nitrogenous compounds can lead to several problems directly related to human health (such as respiratory diseases induced by exposure to high concentrations of ozone due to greenhouse gases) and ecosystem vulnerability (as soil acidification and eutrophication of coastal systems) [13]. Additionally, the intensive use of agrochemicals (fertilizers and pesticides) compromises food safety [14].

Nitrogen is a fundamental mineral nutrient for both plant growth and agricultural yield [15]. It is absorbed by the roots in the form of ammonium or nitrate ion, assimilated by nitrate reductase, and subsequently incorporated into the amino acids [16,17].

The doses of nitrogen fertilizers depend on the crop species, soil and climate conditions, and the $\mathrm{N}$ content in the soil. Each culture requires an appropriate dose of nitrogenous elements concerning its plant cycle [18]. However, excessive application of $\mathrm{N}$ reduces crop yields [19].

An idea of the potential environmental impact of global fertilizer use is provided by the FAO data, according to which today $32 \%$ of the world's land is used for crop production. The projections are that the human population will expand to 9.2 billion in 2050 [20], which will require an increase of food by $70 \%$ and, therefore, an increase in yield, 
with the introduction of new high-yielding cultivars, fertilization, and other cultivation techniques $[21,22]$.

Figure 1 shows how the production of fertilizers in the world has grown to meet the increase in food demand, with a predominant production of nitrogen fertilizers. In 2017, 119 million tons of nitrogen fertilizers were produced, 55 million tons of $\mathrm{P}_{2} \mathrm{O}_{5}$ fertilizers, and 44 million tons of $\mathrm{K}_{2} \mathrm{O}$ fertilizers [23].

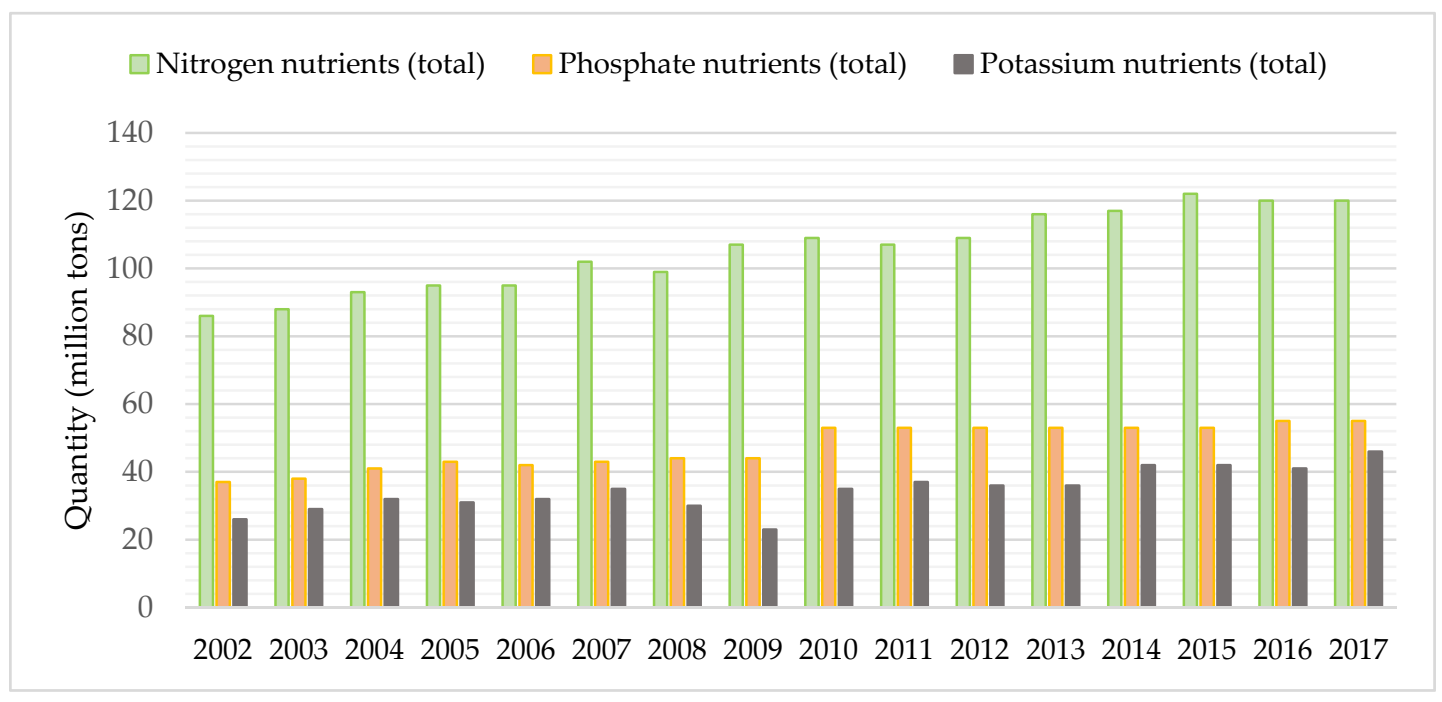

Figure 1. Production of fertilizers worldwide (adapted from Ref: [23]).

In line with fertilizer production, the application of fertilizers in agroecosystems worldwide has also increased. Until a few years ago, the use of nitrogen fertilizers in agricultural land was 109 million tons, followed by phosphorus and potassium fertilizers (Figure 2).

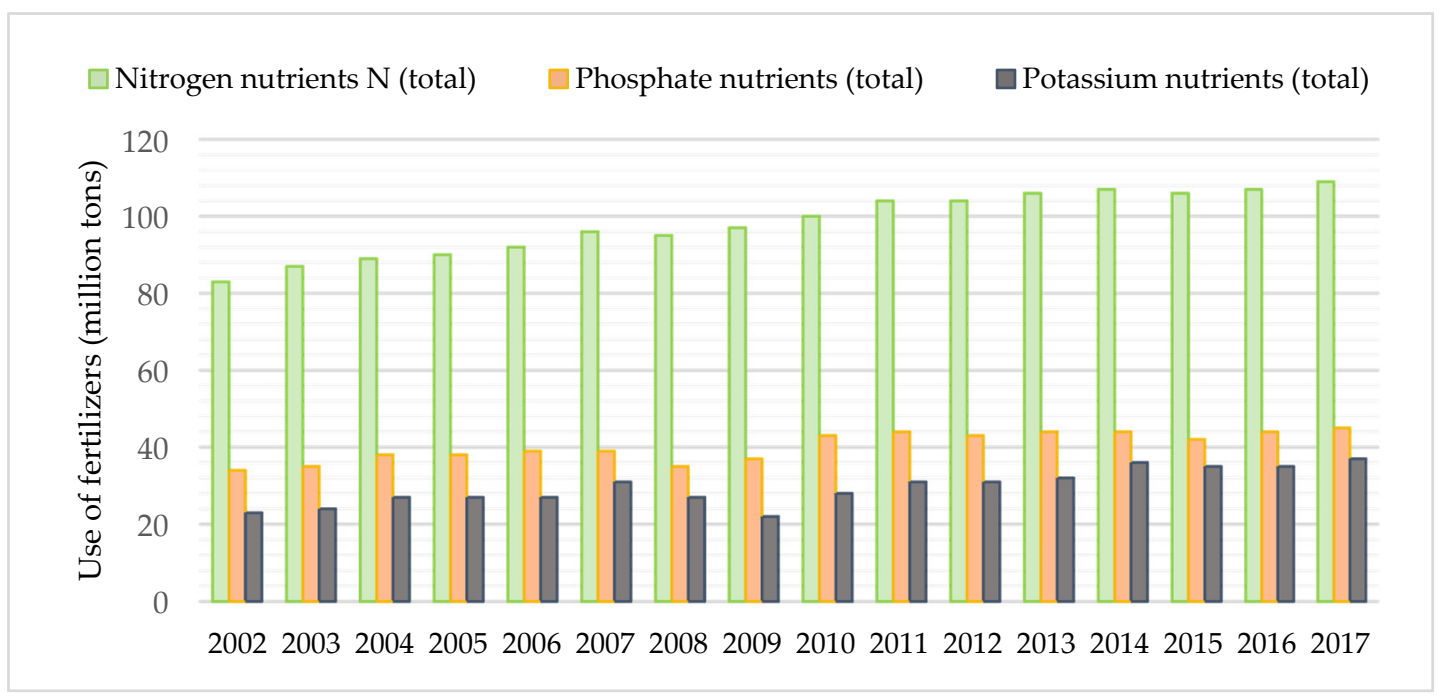

Figure 2. Use of different fertilizer types in agricultural land worldwide (adapted from Ref: [23]).

FAO described an annual growth of the three main fertilizers, namely nitrogen $(\mathrm{N})$, phosphorus expressed in phosphate $\left(\mathrm{P}_{2} \mathrm{O}_{5}\right)$, and potassium expressed in potassium $\left(\mathrm{K}_{2} \mathrm{O}\right)$, of $1.5 \%, 2.2 \%$, and $2.4 \%$, respectively, from 2015 to 2020 , with an application of fertilizers $\mathrm{N}$ equal to 118,763 million tons in 2020 out of 201,663 million tons of fertilizers in total [23]. 
As shown in Figure 3, there are other annual inputs into crop production, such as biological fixation of $\mathrm{N}\left(110 \mathrm{Tg} \mathrm{yr}^{-1}\right)$, recycling of $\mathrm{N}$ from crop residues $\left(16 \mathrm{Tg} \mathrm{yr}^{-1}\right)$ and animal manure (18 $\left.\mathrm{Tg} \mathrm{yr}^{-1}\right)$, atmospheric deposition, and irrigation water [24,25]. Human activity, however, through the high intake of synthetic fertilizers, has a predominant effect on the amount of bioavailable nitrogen [26].

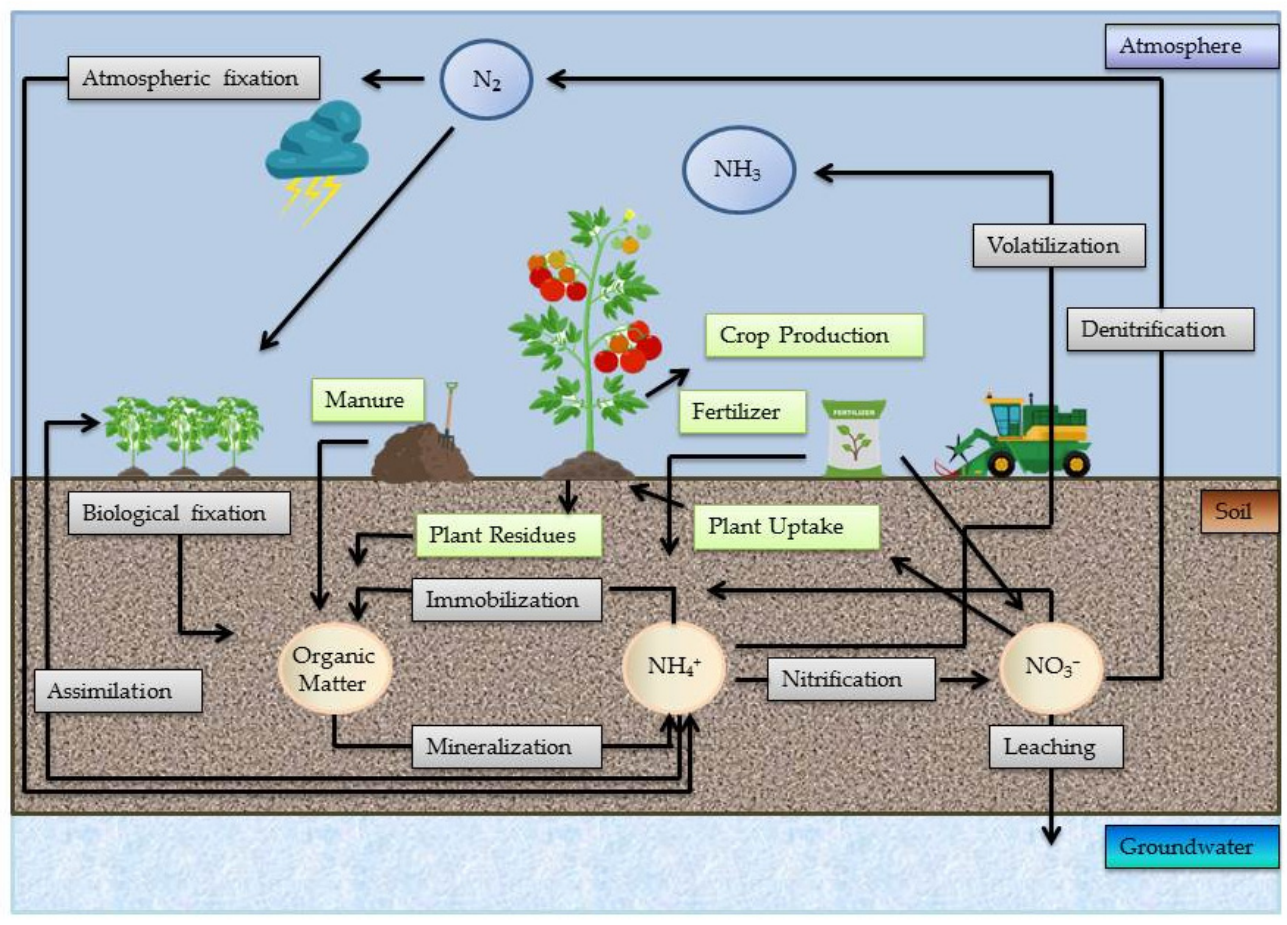

Figure 3. The nitrogen cycle in an agroecosystem.

Agriculture is the world's main driver of environmental change, contributing to the increase in greenhouse gases (methane emissions, carbon monoxide, and nitrous oxide), the eutrophication phenomena, reduction in biodiversity $[27,28]$, as well as air and water pollution $[29,30]$.

One of the most important impacts of agricultural nitrogenous contaminants is the loss of surface water quality and groundwater through the increase in nitrate concentrations. Nitrogen is a key element in plant production and an inappropriate fertilization plan induces eutrophication. The development of algae and macrophytes, the resulting oxygen deficiency, and the development of toxic substances for fish and mammals represent a major global environmental problem [31].

Nitrate leaching is probably the main cause of nitrogen losses of agricultural origin [32-34]. The negative effects of excessive nitrogen fertilization are of increasing concern, stressing the importance of estimating nitrogen losses from agriculture [35] and developing practical nitrogen management strategies to reduce nitrogen leaching in favor of crop yields [36,37].

The aim of this review is to summarize current knowledge on green strategy for recovery from agricultural nitrates in groundwater, taking into account the development of the latest technologies applied for environmental sustainability. Three appropriate sustainable remediation methodologies are presented for the recovery of contaminated sites as a result of nitrate leaching of agricultural origin. In particular, a detailed focus on the ability of biochar to absorb and retain nitrogen compounds is reported.

Finally, a comprehensive European research scoreboard concerning the application of green and sustainable remediation strategies is proposed. 


\section{Green and Sustainable Strategies for Remediation of Nitrate Contaminated Groundwater}

In the last century, agriculture has undergone drastic changes. There has been a reduction in pasture areas, an increase in soil tillage and the use of synthetic fertilizers, and an increase in farm animals per unit of agricultural area. Inorganic nitrogen fertilization practices have led to increased leaching of groundwater nitrates with serious environmental consequences. The results of some field experiments have advised that nitrate leaching responds exponentially rather than linearly to rising $N$ inputs [38-40].

Groundwater is a fundamental natural source for supporting socio-economic development and ensuring the maintenance of the ecological balance of our society [41]. It offers $36 \%$ of drinking water, $42 \%$ of water for agriculture, and $24 \%$ of water for industrial use $[42,43]$. The qualitative property of groundwater resources worldwide is menaced by anthropogenic pollution. Therefore, there is a continuing need to develop advanced nitrogen management practices that increase $\mathrm{N}$ use efficiencies and reduce nitrate-nitrogen leaching.

Agricultural mitigation measures represent a set of traditional and innovative techniques aimed at protecting groundwater and increased efficiency in the use of nitrogen. Manure management and the effective use of organic fertilizers are important to reduce nitrate leaching. Precision fertilization also contributes to sustainable nitrogen application, which can lead to a reduction in nitrogen leaching [39]. Precision farming practices provide technological strategies (for example rate sowing/planting, fertilizing, and irrigation) that reduce agricultural inputs, in relation to the spatial and temporal needs of the fields, with a positive impact on both agricultural production and the environment [44]. Delgado et al. [45] demonstrated how the application of geographic information systems (GIS), global positioning systems (GPS), as well as modelling and remote sensing have maximized the synchronization of $\mathrm{N}$ applications according to culture needs, thus reducing losses of nitrogen compounds by leaching.

Weather conditions are crucial in nitrogen fertilization plans. For example, the application of organic fertilizers in the autumn period leads to increased nitrate leaching [46]. Harvesting crops (usually Lolium, forage radish, and other grassy species) represent a sustainable strategy to reduce the leaching of nitrogen compounds during autumn fertilization by sowing crops early enough [47]. The use of an intermediate crop in the autumn/winter period and the early sowing of winter cereals promote a reduction of the nitrogen surplus [48]. In addition, end-of-season intercalant crops could be an effective strategy for the conservation of $\mathrm{N}$ available after green fertilizer grazing [49].

Green and sustainable remediation (GSR) strategies represent a new approach in the field of soil and groundwater reclamation that has attracted global attention in recent years [50]. GSR technologies for groundwater polluted by nitrates of agricultural origin, including the use of biochar materials, green synthesis of engineered nanoparticles, permeable reactive barriers (PRB), and the release of long-term green remediation materials.

\subsection{Biochar}

Excessive nitrogen fertilization or an unsuitable application timing of the $\mathrm{N}$ distribution induces nitrogen leaching, resulting in a loss of groundwater and surface water quality [51].

For a few years, biochar has been proposed as organic carbon soil (C) amendment to reduce leaching of soil nitrogen compounds [52] and increase the bioavailability of elements for plants. Biochar is a porous carbonaceous material resulting from the pyrolysis of agricultural residues and solid waste, recently widely applied to improve the characteristics of the soil and to recovery environmental matrices [53].

However, the ability of the biochar to reduce the leaching process of nitrates is influenced by type and duration of $\mathrm{N}$ fertilization plan, type of biochar and soil, amount of biochar applied, and the environmental conditions (e.g., temperature, humidity, etc.). 
In relation to the time of treatment, Bochard et al. [54] showed that nitrate leaching was decreased by $13 \%$ with biochar treatment and that the reduction of the leaching process was increased in longer experimental (>26\% in 30-day times). Moreover, Beusch et al. [55] showed that the addition of specific types of biochar led to a significant decrement in nitrate leaching in long experimental times such as the use of woody biochar in a treatment time of eight months.

Studies have evidence that the biochar pre-conditioned with different nitrogen fertilizers promotes vegetative growth by reducing nitrogen nutrient leaching [56,57].

Nitrate leaching is influenced by the combination of two experimental factors such as biochar and soil type and Nguyean et al. [58] showed that the amendment with higher application rates results in a reduction of $\mathrm{NH}_{4}$ in clay soils and no change significant for nitrate. Ghorbani et al. [59] highlighted that soil properties are improved by the biochar, depending on the type of soil that has been amended. Biochar reduces nitrate leaching by $27 \%$ and $23 \%$, respectively, in forest and agricultural soils [60].

Experiments conducted by Li et al. [61] have shown that the choice of method for the application of biochar affects the percentage of nitrate leached in groundwater. In particular, the treatment with $4 \%$ of biochar promotes a maximum reduction of leaching of nitrate of $17 \%$, while a mix of biochar to $2 \%$ in the subsurface soil was found to be effective for the remediation. The importance of the type of treatment for remediation is also highlighted by Dorais et al. [62], who concluded that the reduction of leachate nitrate varies from $30 \%$ to $50 \%$ for soils amended with $10 \%$ and $20 \%$ of biochar, respectively.

Biochar amended soil with rain irrigation reduces the loss of nitrates compared to treatments with full and furrow [63].

Several reviews focused on the impact of biochar on nitrogen flow in agroecosystems. However, the performance of biochar amendment varies considerably with biochar properties and site environments, such as feedstock, dosage, soil characteristics, and treatment time.

According to the state-of-the-art knowledge for the evaluation of the use of biochar as a strategy for the nitrate leaching remediation (Table 2), a few studies have aimed at evaluating the advantages of biochar amendments to soil and the amount of reduced nitrate.

Table 2. Summary of the 2018-2021 latest researches on the biochar application reduction on nitrate leaching and experimental method details.

\begin{tabular}{|c|c|c|c|c|c|c|c|}
\hline $\begin{array}{l}\text { Biochar } \\
\text { Source }\end{array}$ & $\begin{array}{l}\text { Experiment } \\
\text { Type }\end{array}$ & $\begin{array}{c}\text { Treatment } \\
\text { Type }\end{array}$ & $\begin{array}{l}\text { Treatment } \\
\text { Duration }\end{array}$ & Soil Depth & $\begin{array}{l}\mathrm{NO}_{3}^{-} \\
\text {Leaching }\end{array}$ & Advantages & Reference \\
\hline $\begin{array}{l}\text { Rice husk and } \\
\text { populous } \\
\text { wood biochar }\end{array}$ & $\begin{array}{l}\text { Soil column } \\
\text { experiment }\end{array}$ & $\begin{array}{l}\text { Biochar + urea } \\
+ \text { arbuscular } \\
\text { mycorrhizal } \\
\text { fungi }\end{array}$ & 10 weeks & $\begin{array}{l}\text { Entire depth of } \\
\text { the soil column }\end{array}$ & $63-78 \%$ & $\begin{array}{c}\text { Biochar and } \\
\text { mycorrhizal fungi } \\
\text { decreased nitrate } \\
\text { leaching }\end{array}$ & [57] \\
\hline Wheat straw & $\begin{array}{l}\text { Greenhouse } \\
\text { study }\end{array}$ & $\begin{array}{l}\text { Biochar }+ \\
\text { mineral } \\
\text { fertilizer }\end{array}$ & 9 weeks & $\begin{array}{l}\text { Entire depth of } \\
\text { the soil column }\end{array}$ & $34-70 \%$ & $\begin{array}{l}\text { The amount of biochar } \\
\text { applied to soil } \\
\text { determined a different } \\
\text { response in terms of } \\
\text { leached nitrate }\end{array}$ & [64] \\
\hline $\begin{array}{l}\text { Balsam fir + } \\
\text { white and } \\
\text { black spruces }\end{array}$ & $\begin{array}{l}\text { Greenhouse } \\
\text { study }\end{array}$ & $\begin{array}{l}\text { Biochar }+ \\
\text { certified } \\
\text { organic } \\
\text { amendments }\end{array}$ & 3 years & $\begin{array}{l}\text { Half of the } \\
\text { experimental } \\
\text { units }\end{array}$ & $30-50 \%$ & $\begin{array}{l}\text { Biochar in several } \\
\text { organic soils reduced } \\
\text { the nitrogen leaching }\end{array}$ & {$[62]$} \\
\hline Corn stalks & $\begin{array}{l}\text { Soil column } \\
\text { experiment }\end{array}$ & Biochar & 1 year & $\begin{array}{l}\text { Upper half of } \\
\text { the columns }\end{array}$ & $23-27 \%$ & $\begin{array}{c}\text { Soil use and } \\
\text { management can } \\
\text { influence biochar } \\
\text { action in mitigating } \\
\text { nitrate leaching }\end{array}$ & {$[60]$} \\
\hline Canola straws & $\begin{array}{c}\text { Field } \\
\text { experiment }\end{array}$ & Biochar + urea & 4 months & Topsoil & $23-32 \%$ & $\begin{array}{l}\text { Biochar positively } \\
\text { influenced the } \\
\text { reduction of nitrate } \\
\text { leaching in rice fields. }\end{array}$ & {$[65]$} \\
\hline
\end{tabular}


Table 2. Cont.

\begin{tabular}{|c|c|c|c|c|c|c|c|}
\hline $\begin{array}{l}\text { Biochar } \\
\text { Source }\end{array}$ & $\begin{array}{l}\text { Experiment } \\
\text { Type }\end{array}$ & $\begin{array}{l}\text { Treatment } \\
\text { Type }\end{array}$ & $\begin{array}{l}\text { Treatment } \\
\text { Duration }\end{array}$ & Soil Depth & $\begin{array}{l}\mathrm{NO}_{3}^{-} \\
\text {Leaching }\end{array}$ & Advantages & Reference \\
\hline $\begin{array}{l}\text { Feedstock of } \\
\text { mixed hard } \\
\text { and soft virgin } \\
\text { wood }\end{array}$ & $\begin{array}{l}\text { Cranberry } \\
\text { farm }\end{array}$ & $\begin{array}{l}\text { Biochar + } \\
\text { compost }\end{array}$ & 10 weeks & $\begin{array}{l}\text { Entire depth of } \\
\text { the soil column }\end{array}$ & $22-92 \%$ & $\begin{array}{c}\text { Increased biochar } \\
\text { application decreased } \\
\text { ammonium, and nitrate } \\
\text { leaching. }\end{array}$ & [66] \\
\hline $\begin{array}{l}\text { Corncob } \\
\text { biochar }\end{array}$ & $\begin{array}{c}\text { Local } \\
\text { landscaping }\end{array}$ & $\begin{array}{c}\text { Biochar }+ \\
\text { manure or } \\
\text { ammonium } \\
\text { chloride or } \\
\text { sodium nitrate } \\
\end{array}$ & 10 weeks & $\begin{array}{l}\text { Entire depth of } \\
\text { the soil column }\end{array}$ & $19-25 \%$ & $\begin{array}{l}\text { Treatment with biochar } \\
\text { and sodium nitrate } \\
\text { reduced nitrogen losses } \\
\text { more }\end{array}$ & [67] \\
\hline $\begin{array}{c}\text { Apple } \\
\text { branches }\end{array}$ & $\begin{array}{c}\text { Field } \\
\text { experiment }\end{array}$ & Biochar + urea & 2 years & Topsoil & $13-74 \%$ & $\begin{array}{l}\text { Biochar and mineral } \\
\text { nitrogen fertilizers } \\
\text { under the right dosage } \\
\text { conditions reduced the } \\
\text { loss of nitrates. }\end{array}$ & [68] \\
\hline $\begin{array}{c}\text { Apple } \\
\text { branches }\end{array}$ & $\begin{array}{l}\text { Soil column } \\
\text { experiment }\end{array}$ & $\begin{array}{l}\text { Biochar + } \\
\text { ammonium } \\
\text { nitrate }\end{array}$ & $6-20 \mathrm{~h}$ & $\begin{array}{l}\text { Surface layer } \\
\text { of soil; } \\
\text { underlying } \\
\text { soil; the plow } \\
\text { layer of soil }\end{array}$ & $8.3-17 \%$ & $\begin{array}{l}\text { The biochar applied in } \\
\text { the undersoils of } \\
\text { orchards or during } \\
\text { deep processing of } \\
\text { fields is advantageous } \\
\text { for agricultural and } \\
\text { environmental } \\
\text { purposes }\end{array}$ & [61] \\
\hline $\begin{array}{l}\text { Ranches of } \\
\text { oriental plane } \\
\text { tree (Platanus } \\
\text { orientalis) and } \\
\text { dead pig }\end{array}$ & $\begin{array}{c}\text { Field } \\
\text { experiment }\end{array}$ & $\begin{array}{l}\text { Biochar + } \\
\text { ammonium } \\
\text { nitrate }\end{array}$ & 20 weeks & $\begin{array}{l}\text { Entire depth of } \\
\text { the soil column }\end{array}$ & $10-42 \%$ & $\begin{array}{c}\text { Platanus orientalis } \\
\text { branch biochar could } \\
\text { be used to improve } N \\
\text { fertilizer use efficiency } \\
\text { by reducing } N \text { leaching } \\
\text { loss from soils }\end{array}$ & [69] \\
\hline $\begin{array}{l}\text { Winter-pruned } \\
\text { apple branches }\end{array}$ & $\begin{array}{c}\text { Field } \\
\text { experiment }\end{array}$ & $\begin{array}{l}\text { Biochar }+N \\
\text { fertilizer }\end{array}$ & $48 \mathrm{~h}$ & $\begin{array}{l}\text { Entire depth of } \\
\text { the soil column }\end{array}$ & $10-69 \%$ & $\begin{array}{l}\text { Biochar and } \\
\text { nitrogenous fertilizers } \\
\text { in low dose were a } \\
\text { valid strategy to reduce } \\
\text { nitrate leaching and } \\
\text { promote the absorption } \\
\text { of nitrogenous } \\
\text { elements in the plant }\end{array}$ & [70] \\
\hline Spruce chips & $\begin{array}{l}\text { Abandoned } \\
\text { field and } \\
\text { cultivated field }\end{array}$ & Biochar & $\begin{array}{l}19 \text { weeks and } \\
31 \text { weeks }\end{array}$ & $\begin{array}{l}\text { Entire depth of } \\
\text { the soil column }\end{array}$ & $5-31 \%$ & $\begin{array}{l}\text { Biochar retained nitrate } \\
\text { and total nitrogen in } \\
\text { both soils. }\end{array}$ & [71] \\
\hline Pinewood & $\begin{array}{c}\text { Field } \\
\text { experiment }\end{array}$ & $\begin{array}{c}\text { Biochar }+ \\
\text { inorganic } \\
\text { fertilizer } \\
\text { (ammonium } \\
\text { nitrate) or } \\
\text { biosolids } \\
\text { (aerobically } \\
\text { digested Class } \\
\text { B biosolids) }\end{array}$ & 3 years & Topsoil & $60 \%$ & $\begin{array}{l}\text { Soils treated with } \\
\text { biochar and inorganic } \\
\text { fertilizers reduce } \\
\text { nitrate loss }\end{array}$ & [72] \\
\hline $\begin{array}{c}\text { Runks and } \\
\text { branches of } \\
\text { Prosopis juliflora }\end{array}$ & $\begin{array}{c}\text { Field } \\
\text { experiment }\end{array}$ & $\begin{array}{l}\text { Biochar + clay } \\
\text { + urea }\end{array}$ & 16 months & Topsoil & $46 \%$ & $\begin{array}{l}\text { Biochar reduced the } \\
\text { nitrate leaching in } \\
\text { longer experimentation } \\
\text { time }\end{array}$ & [55] \\
\hline $\begin{array}{l}\text { Corncob } \\
\text { biochar }\end{array}$ & $\begin{array}{l}\text { Vegetated filter } \\
\text { strip plots }\end{array}$ & Biochar & 1 year & $\begin{array}{l}\text { Entire depth of } \\
\text { the soil column }\end{array}$ & $40 \%$ & $\begin{array}{l}\text { The biochar in the } \\
\text { surface improved } \\
\text { nitrogen retention }\end{array}$ & [73] \\
\hline $\begin{array}{l}\text { Pinus monticola } \\
\text { wood }\end{array}$ & $\begin{array}{c}\text { Field } \\
\text { experiment }\end{array}$ & $\begin{array}{c}\text { Biochar }+ \\
\text { vermicompost }\end{array}$ & 2 months & $\begin{array}{l}\text { Entire depth of } \\
\text { the soil column }\end{array}$ & $37 \%$ & $\begin{array}{l}\text { Biochar and } \\
\text { vermicompost reduced } \\
\text { the leaching of nitrogen } \\
\text { compounds }\end{array}$ & [74] \\
\hline
\end{tabular}


Table 2. Cont.

\begin{tabular}{|c|c|c|c|c|c|c|c|}
\hline $\begin{array}{l}\text { Biochar } \\
\text { Source }\end{array}$ & $\begin{array}{c}\text { Experiment } \\
\text { Type }\end{array}$ & $\begin{array}{c}\text { Treatment } \\
\text { Type }\end{array}$ & $\begin{array}{l}\text { Treatment } \\
\text { Duration }\end{array}$ & Soil Depth & $\begin{array}{c}\mathrm{NO}_{3}^{-} \\
\text {Leaching }\end{array}$ & Advantages & Reference \\
\hline $\begin{array}{c}\text { Melaleuca } \\
\text { cajuputi waste }\end{array}$ & Forest & Biochar + urea & 5 months & & $29 \%$ & $\begin{array}{c}\text { The use of biochar of } \\
2 \% \text { and } 4 \% \text { in clay soils } \\
\text { reduce nitrogen losses } \\
\text { by } 29.19 \% \text { and } 28.65 \% \\
\text { respectively }\end{array}$ & [75] \\
\hline $\begin{array}{l}\text { Holm oak } \\
\text { biochar }\end{array}$ & $\begin{array}{l}\text { Greenhouse } \\
\text { study }\end{array}$ & $\begin{array}{c}\text { Biochar + NPK } \\
\text { fertilizer }\end{array}$ & 3 months & $\begin{array}{l}\text { Entire depth of } \\
\text { the soil column }\end{array}$ & $26 \%$ & $\begin{array}{l}\text { Biochar reduced the } \\
\text { nitrate leaching to soil } \\
\text { specific depths }\end{array}$ & [76] \\
\hline $\begin{array}{l}\text { Urban green } \\
\text { waste }\end{array}$ & $\begin{array}{c}\text { Field } \\
\text { experiment }\end{array}$ & Biochar + urea & 50 days & Topsoil & $24 \%$ & $\begin{array}{l}\text { Agro-waste biochar } \\
\text { and urea reduced the } \\
\text { use of mineral nitrogen } \\
\text { fertilizers }\end{array}$ & [61] \\
\hline Bagasse & Farm & Biochar + urea & 1 year & $\begin{array}{l}\text { Entire depth of } \\
\text { the soil column }\end{array}$ & $17 \%$ & $\begin{array}{l}\text { Biochar application and } \\
\text { sprinkler irrigation } \\
\text { decreased nitrate } \\
\text { concentration. }\end{array}$ & [63] \\
\hline $\begin{array}{l}\text { Pinus pinaster } \\
\text { and } P \text {. radiata } \\
\text { wood chips }\end{array}$ & $\begin{array}{l}\text { Lysimeter } \\
\text { system }\end{array}$ & $\begin{array}{l}\text { Biochar + pig } \\
\text { slurry }\end{array}$ & 8 months & Topsoil & $\begin{array}{l}\text { Significant } \\
\text { decreased }\end{array}$ & $\begin{array}{l}\text { Freshly added biochar } \\
\text { has a higher adsorbent } \\
\text { capacity than the } \\
\text { biochar naturally aged }\end{array}$ & [77] \\
\hline $\begin{array}{l}\text { Rice husk } \\
\text { biochar }\end{array}$ & $\begin{array}{l}\text { Greenhouse } \\
\text { study }\end{array}$ & Biochar & 10 months & $\begin{array}{l}\text { Entire depth of } \\
\text { the soil column }\end{array}$ & Reduced & $\begin{array}{l}\text { Rice husk biochar } \\
\text { decreased nitrate } \\
\text { leaching principally in } \\
\text { clay soil than loamy } \\
\text { sand }\end{array}$ & [59] \\
\hline $\begin{array}{l}\text { Rice husk } \\
\text { charcoal }\end{array}$ & $\begin{array}{c}\text { Field } \\
\text { experiment }\end{array}$ & $\begin{array}{l}\text { Biochar + } \\
\text { green mulch }\end{array}$ & 28 days & Soil cores & Reduced & $\begin{array}{l}\text { Biochar and mulching } \\
\text { improved the reduction } \\
\text { of nitrate loss. }\end{array}$ & [78] \\
\hline Rice husk & $\begin{array}{c}\text { Field } \\
\text { experiment }\end{array}$ & Biochar + urea & 4 months & Topsoil & Reduced & $\begin{array}{l}\text { Biochar and } \mathrm{N} \\
\text { fertilization improved } \\
\text { rice productivity and } \\
\text { reduced nitrate } \\
\text { leaching }\end{array}$ & [56] \\
\hline Fir woodchips & $\begin{array}{c}\text { Field } \\
\text { experiment }\end{array}$ & Biochar & 1 year & Topsoil & Reduced & $\begin{array}{c}\text { High temperature } \\
\text { biochars reduce nitrate } \\
\text { leaching }\end{array}$ & [79] \\
\hline Spruce biochar & $\begin{array}{l}\text { Boreal grass } \\
\text { field }\end{array}$ & $\begin{array}{c}\text { Biochar + cattle } \\
\text { slurry }\end{array}$ & 3 years & Topsoil & Decreased & $\begin{array}{l}\text { The biochar retained } \\
\text { the nitrate produced by } \\
\text { the use of fertilizers in } \\
\text { the soil }\end{array}$ & {$[71]$} \\
\hline $\begin{array}{l}\text { Rice husk and } \\
\text { rice straw }\end{array}$ & $\begin{array}{c}\text { Field } \\
\text { experiment }\end{array}$ & Biochar + urea & 5 months & Topsoil & $\begin{array}{c}\text { Any } \\
\text { influence }\end{array}$ & $\begin{array}{l}\text { Soil treatment with } \\
\text { biochar reduced } \\
\text { leaching of ammonium } \\
\text { nitrogen }\end{array}$ & [58] \\
\hline Aspen sawdust & $\begin{array}{l}\text { Soil column } \\
\text { experiment }\end{array}$ & Biochar + urea & 4 months & Topsoil & $\begin{array}{c}\text { Any } \\
\text { influence }\end{array}$ & $\begin{array}{c}\text { Sawdust biochar } \\
\text { reduced the } \mathrm{NH}_{4}^{+} \\
\text {concentration in a rice } \\
\text { paddy }\end{array}$ & [80] \\
\hline
\end{tabular}

\subsection{Green Synthesis of Engineered Nanoparticles}

Green synthesis is a novel field aimed at the improvement of engineered nanoparticles (NPs), useful for the remediation of water and soils contaminated by heavy metals, organic pollutants, and synthetic products (for instance pesticides and pharmaceuticals). The advancement of engineered nanoparticles (NPs) has received considerable consideration in the remediation technologies area [81], and among environmental applications, it is possible to inject NP into the subsurface in order to create reducing conditions [82] or to use them as catalysts in waste water [83]. This means that the remediation capacity of NPs depends on chemical and structural properties. 
To remove nitrate from aqueous solutions, several methodologies have been designed and applied, including biological denitrification, chemical reduction, ion exchange, and others.

Denitrification can be accelerated by nano-zero-valent iron (nZVI), as an electron donor with a large specific surface and other reactive activity [84]. Nitrate can then be reduced to nitrite and ion ammonia by nZVI, which in turn can be biodegraded to nitrous oxide and molecular nitrogen through the bacterial denitrification process [85-87]. Wang et al. [88] showed that Alcaligenes sp. TB with $\mathrm{nZVI} / \mathrm{Pd}$ promotes a $31 \%$ nitrate removal in $28 \mathrm{~h}$. The use of nanoscale zero-valent iron/copper supported on chelating resin removed $95 \%$ of nitrate [89]. Liu et al. [90] pointed out that among the best green synthesis strategies, the zero-valent iron-based (ZVI) material represents the most efficient solution for nitrate reduction in groundwater and surface water. Besides, they stressed that the optimization of ZVI performances can be achieved by changing the morphology and structure of ZVI.

Recent research conducted by Manikandan et al. [91] have highlighted that the green synthesis of $\mathrm{NP}_{2} \mathrm{O}_{3}$ from Prunus $x$ yedoensis leaf extract (PYLE), have promising applications in the removal of nitrates in environmental samples. The green synthesis of iron nanoparticles (INP) under aerobic and anaerobic conditions via nitrate reductase enzymes (NAP/ NAR) generated by Proteus mirabilis strain 10B was tested for denitrification power in wastewater samples (urban, agricultural, and industrial) [92]. The results of the study make it possible to propose the INPs as a valid candidate in bioremediation activities of nitrate pollution.

With regard to technologies to remove nitrate from water polluted by agricultural contaminants, catalytic reduction has attracted increasing attention as it is characterized by a high bioremedial capacity, with lower costs than other methods [93]. The use of biometallic catalysts based on a noble metal such as palladium (Pd) and a transition metal such as copper $(\mathrm{Cu})$ represent one of the most used supports for nitrate reduction [94]. Indeed, Perez-Coronado et al. [93] demonstrated that a new approach based on the screening of active Pd sites in PdCu catalysts by sodium bis-2-ethylhexyl sulfosuccinate (AOT) causes a decrease in activity for nitrate reduction. A cost-effective and stable three-dimensional Pdoped $\mathrm{Co}_{3} \mathrm{O}_{4} /$ nickel foam has been used in order to promote the electrocatalytic reduction of $\mathrm{NO}_{3}{ }^{-}$in water [95].

The addition of 2-D graphite carbon nanoparticles, produced by electrochemical processes, to fertilizer mixtures was performed during an experiment involving the cultivation of romaine lettuce [96]. Research has shown that the use of NPs could allow farmers to apply fewer fertilizers, achieving high production yields and reducing the amount of nitrates reaching the surrounding water bodies.

\subsection{Permeable Reactive Barriers}

The methods of nitrate removal from the groundwater provide for the application of physical, chemical, and biological methodologies. The electrochemical method, mainly preferred by researchers, shows limitations including the high number of by-products [97]. The bio-denitrification process based on the permeable reactive barrier (PRB) is now considered one of the most effective and promising technologies for the recovery of nitrates in environmental matrices [98]. As shown in Figure 4, PBR is a porous reactive material positioned along the path of a plume of subterranean water in order to remove nitrates from the plume as it passes through it [99]. 


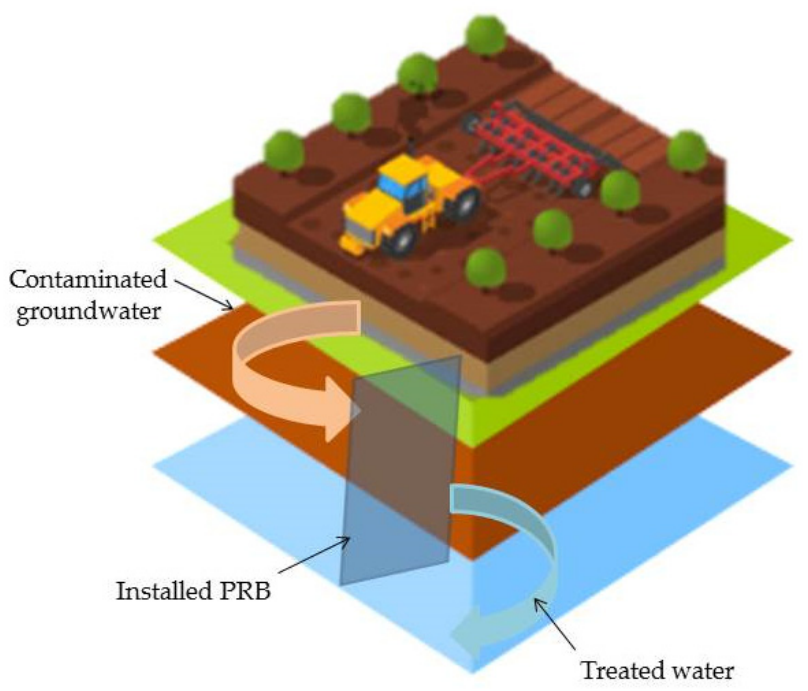

Figure 4. Representation of the location of the PRB relative to a high nitrate groundwater flow path.

The effectiveness of PRBs in improving the quality of groundwater contaminated by nitrogen pollutants has been proved by several authors. The barriers can be made from different types of material. In addition, factors influencing the nitrate removal capacity include carbon sources, temperature, and hydraulic conditions. Mittal et al. [100] show that absorption capacity decreases if the temperature exceeds $45^{\circ} \mathrm{C}$ due to change in chemical potential at higher temperatures. Table 3 summarizes the results obtained from 2016 to date.

Table 3. Percentage of nitrate removed according to the type of material as a carbon source.

\begin{tabular}{ccc}
\hline Substrate Type & Nitrate Removal \% & References \\
\hline Corncob & $86-100$ & {$[101]$} \\
Fly ash and rice husk & 95 & {$[100]$} \\
Woodchip & 40 & {$[102]$} \\
Tea factory waste and hazelnut husk & $40-100$ & {$[103]$} \\
Alternative latrine and waste materials & $13-57$ & {$[104]$} \\
Mixture of gravel and mulching & 97 & {$[105]$} \\
Wood shavings or biochar & $33-37$ & {$[106]$} \\
Mixture of Fe, activated carbon and coarse sand & 92 & {$[107]$} \\
Granular cast ZVI & $15-20$ & {$[108]$} \\
Poly(3-hydroxybutyrate-co-hydroxyvalerate) (PHBV) and & 95 & {$[109]$} \\
\hline
\end{tabular}

The use of PBR provides a viable economic and ecological alternative for the remediation of polluting groundwater from nitrogenous contaminants of agricultural origin. Studies suggest that the recovery and use of waste materials for the construction of barriers is an increasingly widespread ecological strategy.

\section{Sustainable and Green Remediation Strategies in Europe: Research Studies and Field-Scale Applications}

Clean water is a vital resource for human health and well-being, so safeguarding water quality is one of the cornerstones of European environmental policy. The 1991 Nitrates Directive is one of the first EU legislation aimed at controlling water pollution by agricultural contaminants and improving water quality [110]. Nitrogen is an essential nutrient for agricultural production and population growth is leading to the use of high concentrations of nitrogen elements in agroecosystems. The massive distribution of chemical and organic fertilizers is the main source of water pollution in Europe. 
In recent decades we have already witnessed profound changes in modern society and the "green revolution" in place recalls the need to disseminate the latest sustainable technologies in both the scientific and economic system.

As shown in Figure 5, from 2000 to date, scientific research in the field of green and sustainable remediation (GSR) has increased. Among the three technologies described above, the use of biochar is the green strategy mainly researched, in Europe and around the world, to reduce pollution caused by the increase in agricultural nitrates. In contrast, the use of nanoparticles has not yet been explored by European researchers.

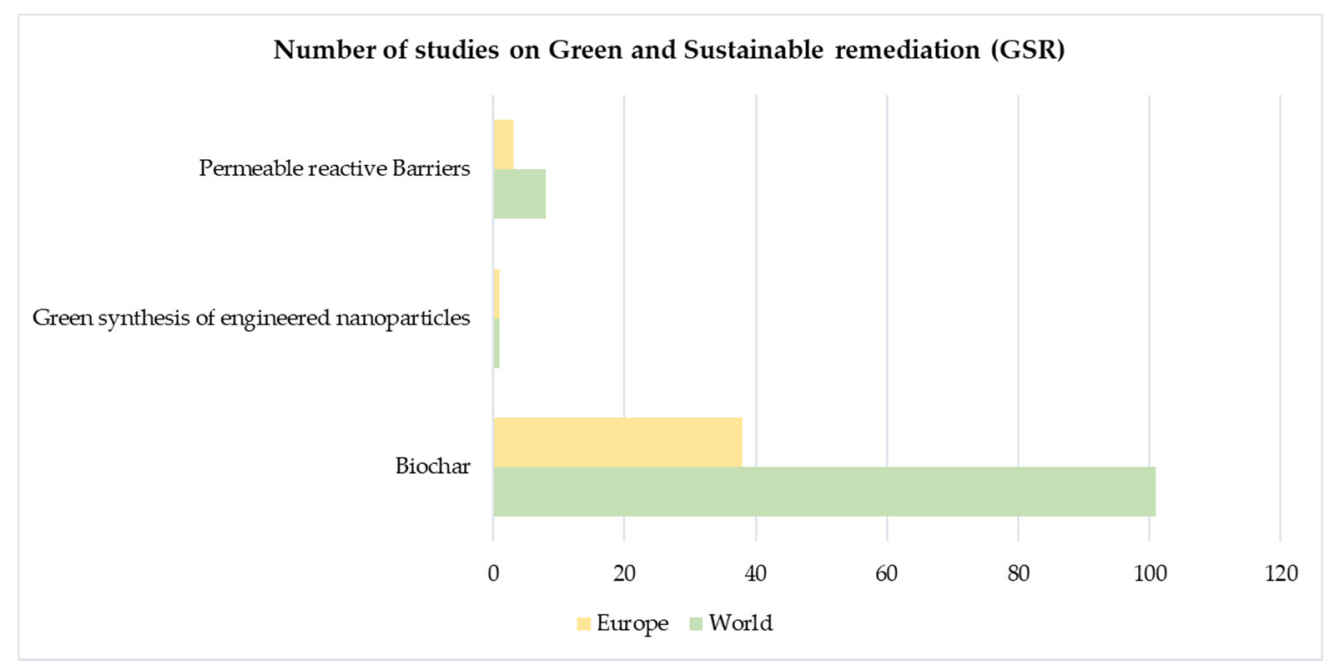

Figure 5. Number of studies on the different types of Green and Sustainable Remediation carried out in Europe (in yellow) and in the world (in green) from 2000 to today. Source: Scopus database (http://www.scopus.com/ accessed on 29 April 2021).

In particular, the GSR studies focused on the biochar's ability to bind nitrate, reducing the percentage of leached nitrogen compound in surface and groundwater. Of the 101 papers on biochar published, Europe has contributed 38 publications. The United Kingdom was the European country which published the largest number of scientific papers (9), followed by Spain and Germany (6) and Italy (5). Ireland has published five articles on the application of biochar for environmental purposes as Italy. From 2017 to today, Finland has contributed an article for each year, indicating a recent and continuous interest in the remediation strategy. Worldwide, China is the nation with the largest number of publications, as it is the world's largest producer of crop residues [111], followed by the United States.

The analysis of the keywords allows to reveal the characteristics and the tendencies of development of the field [112]. During the bibliographic study for the biochar, the words "biochar" and "nitrate leaching" were used.

In reference to published work on engineered nanoparticles (NPs) [113], the number of publications is only one. In fact, green synthesis is a new emerging field with the aim of developing and improving the production of effective and ecological nanoparticles. India is the country that contributed to deepening the challenges for the synthesis of NPs products for environmental recovery.

For the period under examination, the bibliographical search through the keywords has previewed the insertion of the words "green nanoparticles" and "nitrate leaching".

Finally, the graph in Figure 5 shows the recent attention in investigating the potential of permeable reactive barriers in the field of sustainable green technologies [114]. From 2000 to 2021, bibliographic research using the keywords "permeable reactive barriers" and "nitrate leaching" returned eight publications. China is the country that has begun to study the ability of barriers to reduce the nitrogen contamination from agricultural practices. In 
Europe, the countries that are carrying out research and application studies on permeable barriers are Belgium, Italy, and the United Kingdom.

\section{Conclusions}

The importance of sustainability in agriculture and the growth of the world's population requires the implementation of adequate nitrogen management strategies and fertilization techniques, capable of preserving both the quality of environmental matrices and crop yields.

High nitrate concentrations in water bodies due to $\mathrm{N}$ soil leaching cause nitrate pollution of drinking water and, as a consequence, excess $\mathrm{N}$ levels change the ecological balance of the natural resources. This review describes and discusses environmental pollution by agricultural practices and the most recent green and sustainable remediation (GSR) strategies developed to limit nitrate pollution, such as the use of biochar, engineered nanoparticles, and permeable reactive barriers.

Special attention is paid to biochar, employed usefully as a soil improver and to reduce the concentrations of environmental contaminants. Prior to defining the optimal remediation protocols, it is necessary to consider and study the biochar favorable properties i.e., biochar type, fertilization type, and characteristics of soil. The performance, in terms of nitrate leaching reduction percentage, achieved with the rice husk and wood biochar in urea-arbuscular mycorrhizal fungi-fertilized soils was the highest found in literature, with an average value of $70 \%$. The fir biochar was instead found to be the most performing in experiments conducted in soil treating with organic fertilizers. In addition, several research studies have shown that the use of biochar allows for a reduction in the employment of nitrogenous fertilizers thus preserving groundwater quality.

Green synthesis is an emerging multidisciplinary area aimed at improving engineered nanoparticles (NPs) for the recovery of environmental matrices from agricultural origin organic contaminants. Among the best GSRs, zero valence, iron-based material (ZVI) is the most efficient solution for reducing nitrates in groundwater. In fact, the use of these NPs has proven highly promising, with a nitrate removal of 31-95\%.

Finally, in this review, we have described how the use of PRBs is a valid ecological strategy for the remediation of water bodies polluted by $\mathrm{N}$ contaminants.

The highest percentage of nitrate removal has been achieved using permeable barriers consisting of corncob biochar and fly ash-rice husk biochar, confirming the carbanions soil improver as a valid green material for environmental remediation.

Using biochar is the main sustainable strategy currently adopted in Europe for the recovery of environmental matrices from agricultural pollution.

Author Contributions: Conceptualization, D.L. and V.A.; writing—original draft preparation, D.L., V.A., D.D.P., M.T., C.M. and A.G.; writing—review and editing, V.A. and D.L.; providing case and idea, V.A., D.L. and V.F.U.; supervision, V.A.; references collection, D.L., D.D.P., M.T., C.M. and A.G.; funding acquisition, V.F.U. All authors have read and agreed to the published version of the manuscript.

Funding: This work was supported by the project "Attuazione Direttiva 91/676/CEE relativa alla protezione delle acque dall'inquinamento provocato dai nitrati provenienti da fonti agricoleart. 92 del D. Lgs. 152/2006-Revisione delle Zone Vulnerabili da Nitrati di origine agricola e aggiornamento del Programma d'Azione Nitrati-Convenzione tra Regione Puglia e CNR-IRSA di Bari del 27/11/2019".

Institutional Review Board Statement: Not applicable.

Informed Consent Statement: Not applicable.

Data Availability Statement: Data sharing not applicable.

Conflicts of Interest: The authors declare no conflict of interest. 


\section{References}

1. Frink, C.R.; Waggoner, P.E.; Ausubel, J.H. Nitrogen fertilizer: Retrospect and prospect. Proc. Natl. Acad. Sci. USA 1999, 96, 1175-1180. [CrossRef]

2. FAO. World Fertilizer Trends and Outlook to 2018; Food \& Agriculture Organization: Rome, Italy, 2015; ISBN 9789251086926.

3. Xiong, L.; Sun, W.J.; Cai, H.Y.; Yang, Y.; Zhu, J.; Zhao, B. wen Correlation of enhancement degree on contrast-enhanced ultrasound with histopathology of carotid plaques and serum high sensitive C-reactive protein levels in patients undergoing carotid endarterectomy. J. Huazhong Univ. Sci. Technol. Med. Sci. 2017, 37, 425-428. [CrossRef] [PubMed]

4. Ju, X.; Lu, X.; Gao, Z.; Chen, X.; Su, F.; Kogge, M.; Römheld, V.; Christie, P.; Zhang, F. Processes and factors controlling $\mathrm{N}_{2} \mathrm{O}$ production in an intensively managed low carbon calcareous soil under sub-humid monsoon conditions. Environ. Pollut. 2011, 159, 1007-1016. [CrossRef]

5. Hoang, V.N.; Alauddin, M. Assessing the eco-environmental performance of agricultural production in OECD countries: The use of nitrogen flows and balance. Nutr. Cycl. Agroecosyst. 2010, 87, 353-368. [CrossRef]

6. Santamaria, P. Nitrate in vegetables: Toxicity, content, intake and EC regulation. J. Sci. Food Agric. 2006, 86, 10-17. [CrossRef]

7. Lazare, S.; Lyu, Y.; Yermiyahu, U.; Heler, Y.; Ben-Gal, A.; Holland, D.; Dag, A. Optimizing nitrogen application for growth and productivity of pomegranates. Agronomy 2020, 10, 366. [CrossRef]

8. Janssen, B.H. Agriculture and the nitrogen cycle, Assessing the impact of fertilizer use on food production and the environment. Geoderma 2006, 134, 233-234. [CrossRef]

9. Anderson, M.G.; Katz, P.B. Strategic Sourcing. Int. J. Logist. Manag. 1998, 9, 1-13. [CrossRef]

10. Wang, M.; Pendall, E.; Fang, C.; Li, B.; Nie, M. A global perspective on agroecosystem nitrogen cycles after returning crop residue. Agric. Ecosyst. Environ. 2018, 266, 49-54. [CrossRef]

11. Vitousek, P.M.; Naylor, R.; Crews, T.; David, M.B.; Drinkwater, L.E.; Holland, E.; Johnes, P.J.; Katzenberger, J.; Martinelli, L.A.; Matson, P.A.; et al. Nutrient imbalances in agricultural development. Science 2009, 324, 1519-1520. [CrossRef]

12. Drinkwater, L.E.; Snapp, S.S. Nutrients in Agroecosystems: Rethinking the Management Paradigm. Adv. Agron. 2007, 92, 163-186.

13. Optimizing Nitrogen Management in Food and Energy Production and Environmental Protection-Google Libri. Available online: https://books.google.it/books?hl=it\&lr=\&id=ADvJ3vcVwVIC\&oi=fnd\&pg=PP17\&dq=nitrogen+man agement+food+and+energy+production\&ots=YmzUM604_Y\&sig=UGn8T6WAoX044VZxz4pRKWDloYY\#v=onepage\&q=nitr ogenmanagementfoodandenergyproduction\&f=false (accessed on 22 March 2021).

14. Xiang, T.; Malik, T.H.; Nielsen, K. Technological Forecasting \& Social Change The impact of population pressure on global fertiliser use intensity, 1970-2011: An analysis of policy-induced mediation. Technol. Forecast. Soc. Chang. 2020, 152, 119895. [CrossRef]

15. Tsouvaltzis, P.; Kasampalis, D.S.; Aktsoglou, D. Effect of Reduced Nitrogen and Supplemented Amino Acids Nutrient Solution on the Nutritional Quality of Baby Green and Red Lettuce Grown in a Floating System. Agronomy 2020, 10, 922. [CrossRef]

16. Blom-Zandstra, M. Nitrate accumulation in vegetables and its relationship to quality. Ann. Appl. Biol. 1989, 115, 553-561. [CrossRef]

17. Padgett, P.E.; Leonard, R.T. Regulation of nitrate uptake by amino acids in maize cell suspension culture and intact roots. Plant. Soil 1993, 155-156, 159-161. [CrossRef]

18. Conditions, N. Efficient Physiological and Nutrient Use E ffi ciency Responses of Maize Leaves to Drought Stress under. Agronomy 2020, 10, 523.

19. Jin, L.; Cui, H.; Li, B.; Zhang, J.; Dong, S.; Liu, P. Effects of integrated agronomic management practices on yield and nitrogen efficiency of summer maize in North China. Field Crop. Res. 2012, 134, 30-35. [CrossRef]

20. Popp, J.; Pető, K.; Nagy, J. Pesticide productivity and food security. A review. Agron. Sustain. Dev. 2013, 33, 243-255. [CrossRef]

21. Oerke, E.C.; Dehne, H.W. Safeguarding production-Losses in major crops and the role of crop protection. Crop. Prot. 2004, 23, 275-285. [CrossRef]

22. Meseldžija, M.; Rajković, M.; Dudić, M.; Vranešević, M.; Bezdan, A.; Jurišić, A.; Ljevnaić-Mašić, B. Economic feasibility of chemical weed control in soybean production in Serbia. Agronomy 2020, 10, 291. [CrossRef]

23. FAO. World Fertilizer Trends and Outlook to 2020: Summary Report; Food \& Agriculture Organization: Rome, Italy, 2017 ; p. 38.

24. Smil, V. Nitrogen in crop production: An account of global flows. Glob. Biogeochem. Cycles 1999, 13, 647-662. [CrossRef]

25. Kuypers, M.M.M.; Marchant, H.K.; Kartal, B. The microbial nitrogen-cycling network. Nat. Rev. Microbiol. 2018, 16, 263-276. [CrossRef]

26. Galloway, J.N.; Townsend, A.R.; Erisman, J.W.; Bekunda, M.; Cai, Z.; Freney, J.R.; Martinelli, L.A.; Seitzinger, S.P.; Sutton, M.A. Transformation of the nitrogen cycle: Recent trends, questions, and potential solutions. Science 2008, 320, 889-892. [CrossRef]

27. Galloway, J.N.; Aber, J.D.; Erisman, J.A.N.W.; Sybil, P.; Howarth, R.W.; Cowling, E.B.; Cosby, B.J. The Nitrogen Cascade. Bioscience 2003, 53, 341-356. [CrossRef]

28. Schlesinger, W.H. On the fate of anthropogenic nitrogen. Proc. Natl. Acad. Sci. USA 2015. [CrossRef]

29. Adegbeye, M.J.; Ravi Kanth Reddy, P.; Obaisi, A.I.; Elghandour, M.M.M.Y.; Oyebamiji, K.J.; Salem, A.Z.M.; Morakinyo-Fasipe, O.T.; Cipriano-Salazar, M.; Camacho-Díaz, L.M. Sustainable agriculture options for production, greenhouse gasses and pollution alleviation, and nutrient recycling in emerging and transitional nations-An overview. J. Clean. Prod. 2020, 242, 118319. [CrossRef]

30. Charles, H.; Godfray, H.; Garnett, T. Food security and sustainable intensification. Philos. Trans. R. Soc. B Biol. Sci. 2014, 369. [CrossRef] 
31. Howarth, R.W.; Billen, G.; Swaney, D.; Townsend, A.; Jaworski, N.; Lajtha, K.; Downing, J.A.; Elmgren, R.; Caraco, N.; Jordan, T.; et al. Regional nitrogen budgets and riverine N \& P fluxes for the drainages to the North Atlantic Ocean: Natural and human influences. Biogeochemistry 1996, 35, 75-139. [CrossRef]

32. Survey, R.; Scientific, C. Nitrate Distribution in Tropical Many investigators in the tropics report high nitrate content in the topsoil during the drier part of the year (Schofield ${ }^{9}$, Hardy $^{3}$, Meiklejohn ${ }^{6}$, Jones ${ }^{4}$ ). This phenomenon is not as yet unde. Plant. Soil 1961, $15,110-120$.

33. Undisturbed, T.; Columns, S.; Pleysier, J.L.; Juo, A.S.R. Leaching of Fertilizer Ions in a Ultisol from the High Rainfall Tropics: Leaching. History 3. Available online: https://acsess.onlinelibrary.wiley.com/doi/abs/10.2136/sssaj1981.0361599500450004001 6x (accessed on 28 April 2021).

34. Oafoku, N. Overview of different aspects of climate change effects on soils. In Climate Change Effects on Soils: Aspects and Considerations; Nova Science Publishers: Hauppauge, NY, USA, 2015; pp. 1-59. ISBN 9781634827744.

35. Xu, L.; Niu, H.; Xu, J.; Wang, X. Nitrate-nitrogen leaching and modeling in intensive agriculture farmland in China. Sci. World J. 2013, 2013. [CrossRef]

36. Min, J.; Zhang, H.; Shi, W. Optimizing nitrogen input to reduce nitrate leaching loss in greenhouse vegetable production. Agric. Water Manag. 2012, 111, 53-59. [CrossRef]

37. Russelle, M.P.; Lamb, J.A.F.S.; Turyk, N.B.; Shaw, B.H.; Pearson, B. Managing nitrogen contaminated soils: Benefits of N2-fixing alfalfa. Agron. J. 2007, 99, 738-746. [CrossRef]

38. Wang, Y.; Ying, H.; Yin, Y.; Zheng, H.; Cui, Z. Estimating soil nitrate leaching of nitrogen fertilizer from global meta-analysis. Sci. Total Environ. 2019, 657, 96-102. [CrossRef]

39. Delin, S.; Stenberg, M. Effect of nitrogen fertilization on nitrate leaching in relation to grain yield response on loamy sand in Sweden. Eur. J. Agron. 2014, 52, 291-296. [CrossRef]

40. Goulding, K.W.T.; Poulton, P.R.; Webster, C.P.; Howe, M.T. Nitrate leaching from the broadbalk wheat experiment, Rothamsted, UK, as influenced by fertilizer and manure inputs and the weather. Soil Use Manag. 2000, 16, 244-250. [CrossRef]

41. Zaporozec, A. Ground-Water pollution and its sources. GeoJournal 1981, 5, 457-471. [CrossRef]

42. Hao, A.; Zhang, Y.; Zhang, E.; Li, Z.; Yu, J.; Wang, H.; Yang, J.; Wang, Y. Review: Groundwater resources and related environmental issues in China. Hydrogeol. J. 2018, 26, 1325-1337. [CrossRef]

43. Döll, P.; Hoffmann-Dobrev, H.; Portmann, F.T.; Siebert, S.; Eicker, A.; Rodell, M.; Strassberg, G.; Scanlon, B.R. Impact of water withdrawals from groundwater and surface water on continental water storage variations. J. Geodyn. 2012, 59-60, 143-156. [CrossRef]

44. Balafoutis, A.; Beck, B.; Fountas, S.; Vangeyte, J.; Van Der Wal, T.; Soto, I.; Gómez-Barbero, M.; Barnes, A.; Eory, V. Precision agriculture technologies positively contributing to ghg emissions mitigation, farm productivity and economics. Sustainability 2017, 9, 1339. [CrossRef]

45. Delgado, J.A.; Bausch, W.C. Potential use of precision conservation techniques to reduce nitrate leaching in irrigated crops. J. Soil Water Conserv. 2005, 60, 379-387.

46. Hellsten, S.; Dalgaard, T.; Rankinen, K.; Tørseth, K.; Bakken, L.; Bechmann, M.; Kulmala, A.; Moldan, F.; Olofsson, S.; Piil, K.; et al. Abating N in Nordic agriculture-Policy, measures and way forward. J. Environ. Manag. 2019, 236, 674-686. [CrossRef] [PubMed]

47. De Waele, J.; Vandecasteele, B.; Elsen, A.; Haesaert, G.; Wittouck, D.; Horemans, D.; Zerssa, G.W.; De Neve, S. Risk assessment of additional nitrate leaching under catch crops fertilized with pig slurry after harvest of winter cereals. Agric. Ecosyst. Environ. 2020, 304, 107113. [CrossRef]

48. Vogeler, I.; Jensen, J.L.; Thomsen, I.K.; Labouriau, R.; Hansen, E.M. Fertiliser N rates interact with sowing time and catch crops in cereals and affect yield and nitrate leaching. Eur. J. Agron. 2021, 124. [CrossRef]

49. Cicek, H.; Martens, J.R.T.; Bamford, K.C.; Entz, M.H. Late-season catch crops reduce nitrate leaching risk after grazed green manures but release N slower than wheat demand. Agric. Ecosyst. Environ. 2015, 202, 31-41. [CrossRef]

50. Chen, Q.; Fan, G.; Na, W.; Liu, J.; Cui, J.; Li, H. Past, present, and future of groundwater remediation research: A scientometric analysis. Int. J. Environ. Res. Public Health 2019, 16, 3975. [CrossRef]

51. Shi, W.; Ju, Y.; Bian, R.; Li, L.; Joseph, S.; Mitchell, D.R.G.; Munroe, P.; Taherymoosavi, S.; Pan, G. Science of the Total Environment Biochar bound urea boosts plant growth and reduces nitrogen leaching. Sci. Total Environ. 2020, 701, 134424. [CrossRef] [PubMed]

52. Blanco-Canqui, H. Biochar and Water Quality. J. Environ. Qual. 2019, 48, 2-15. [CrossRef]

53. Sashidhar, P.; Kochar, M.; Singh, B.; Gupta, M.; Cahill, D.; Adholeya, A.; Dubey, M. Biochar for delivery of agri-inputs: Current status and future perspectives. Sci. Total Environ. 2019, 134892. [CrossRef]

54. Borchard, N.; Schirrmann, M.; Cayuela, M.L.; Kammann, C.; Wrage-Mönnig, N.; Estavillo, J.M.; Fuertes-Mendizábal, T.; Sigua, G.; Spokas, K.; Ippolito, J.A.; et al. Biochar, soil and land-use interactions that reduce nitrate leaching and N2O emissions: A meta-analysis. Sci. Total Environ. 2019, 651, 2354-2364. [CrossRef]

55. Beusch, C.; Cierjacks, A.; Böhm, J.; Mertens, J.; Bischoff, W.A.; de Araújo Filho, J.C.; Kaupenjohann, M. Biochar vs. clay: Comparison of their effects on nutrient retention of a tropical Arenosol. Geoderma 2019, 337, 524-535. [CrossRef]

56. Oladele, S.O.; Adeyemo, A.J.; Awodun, M.A. Influence of rice husk biochar and inorganic fertilizer on soil nutrients availability and rain-fed rice yield in two contrasting soils. Geoderma 2019, 336, 1-11. [CrossRef]

57. Abbaspour, A.; Asgari, H. Effect of biochar on nitrogen retention in soil under corn plant inoculated with arbuscular mycorrhizal fungi. Adv. Environ. Technol. 2019, 5, 133-140. [CrossRef] 
58. Nguyen, B.T.; Phan, B.T.; Nguyen, T.X.; Nguyen, V.N.; Van Tran, T.; Bach, Q.V. Contrastive nutrient leaching from two differently textured paddy soils as influenced by biochar addition. J. Soils Sediments 2020, 20, 297-307. [CrossRef]

59. Ghorbani, M.; Asadi, H.; Abrishamkesh, S. International Soil and Water Conservation Research Effects of rice husk biochar on selected soil properties and nitrate leaching in loamy sand and clay soil. Int. Soil Water Conserv. Res. 2019, 7, 258-265. [CrossRef]

60. Kanthle, A.K.; Lenka, N.K.; Tedia, K. Land use and biochar effect on nitrate leaching in a Typic Haplustert of central India. Catena 2018, 167, 422-428. [CrossRef]

61. Li, S.; Zhang, Y.; Yan, W.; Shangguan, Z. Soil \& Tillage Research Effect of biochar application method on nitrogen leaching and hydraulic conductivity in a silty clay soil. Soil Tillage Res. 2018, 183, 100-108. [CrossRef]

62. Dorais, M.; Gagnon, F.; Laurin-lancto, S.; The, M.; Me, C.; Pepin, S. Short-term improvement of soil biological activity in biochar-amended organic greenhouse tomato crops. Acta Hortic. 2017, 249-256. [CrossRef]

63. Farahani, S.S.; Asoodar, M.A.; Moghadam, B.K. Short-term impacts of biochar, tillage practices, and irrigation systems on nitrate and phosphorus concentrations in subsurface drainage water. Environ. Sci. Pollut. Res. 2020, 27, 761-771. [CrossRef] [PubMed]

64. Crutchfield, E.F.; McGiffen, M.E.; Merhaut, D.J. Effects of biochar on nutrient leaching and begonia plant growth. J. Environ. Hortic. 2018, 36, 126-132. [CrossRef]

65. Sun, H.; Min, J.; Zhang, H.; Feng, Y.; Lu, K.; Shi, W.; Yu, M.; Li, X. Biochar application mode influences nitrogen leaching and NH3 volatilization losses in a rice paddy soil irrigated with N-rich wastewater. Environ. Technol. 2018, 39, 2090-2096. [CrossRef]

66. Rubin, R.L.; Anderson, T.R.; Ballantine, K.A. Biochar Simultaneously Reduces Nutrient Leaching and Greenhouse Gas Emissions in Restored Wetland Soils. Wetlands 2020, 40, 1981-1991. [CrossRef]

67. Sanford, J.R.; Larson, R.A. Assessing Nitrogen Cycling in Corncob Biochar Amended Soil Columns for Application in Agricultural Treatment Systems. Agronomy 2020, 10, 979. [CrossRef]

68. Li, S.; Wang, S.; Shangguan, Z. Combined biochar and nitrogen fertilization at appropriate rates could balance the leaching and availability of soil inorganic nitrogen. Agric. Ecosyst. Environ. 2019, 276, 21-30. [CrossRef]

69. Feng, Y.; Yang, X.; Singh, B.P.; Mandal, S.; Guo, J.; Che, L.; Wang, H. Effects of contrasting biochars on the leaching of inorganic nitrogen from soil. J. Soils Sediments 2020, 20, 3017-3026. [CrossRef]

70. Cao, H.; Ning, L.; Xun, M.; Feng, F.; Li, P.; Yue, S.; Song, J.; Zhang, W.; Yang, H. Biochar can increase nitrogen use efficiency of Malus hupehensis by modulating nitrate reduction of soil and root. Appl. Soil Ecol. 2019, 135, 25-32. [CrossRef]

71. Saarnio, S.; Kettunen, R. Biochar addition affected nutrient leaching and litter decomposition rates in boreal sandy soils. Agric. Food Sci. 2020, 29, 287-296. [CrossRef]

72. Lu, Y.; Silveira, M.L.; O'Connor, G.A.; Vendramini, J.M.B.; Erickson, J.E.; Li, Y.C.; Cavigelli, M. Biochar impacts on nutrient dynamics in a subtropical grassland soil: 1. Nitrogen and phosphorus leaching. J. Environ. Qual. 2020, 49, 1408-1420. [CrossRef] [PubMed]

73. Sanford, J.R.; Larson, R.A. Treatment of horizontal silage bunker runoff using biochar amended vegetative filter strips. J. Environ. Manag. 2020, 253, 109746. [CrossRef] [PubMed]

74. Alvarez, J.M.; Pasian, C.; Lal, R.; López, R.; Fernández, M. Vermicompost and biochar substrates can reduce nutrients leachates on containerized ornamental plant production. Hortic. Bras. 2019, 37, 47-53. [CrossRef]

75. Nurmalasari, A.I.; Suryanto, P.; Alam, T. Effectiveness of Melaleuca cajuputi biochar as a leaching loss for nitrogen fertilizer and intercropping in maize. Indian J. Agric. Res. 2020, 54, 506-510. [CrossRef]

76. Demiraj, E.; Libutti, A.; Malltezi, J.; Rroço, E.; Brahushi, F.; Monteleone, M.; Sulçe, S. Effect of organic amendments on nitrate leaching mitigation in a sandy loam soil of Shkodra district, Albania. Ital. J. Agron. 2018, 13, 93-102. [CrossRef]

77. Llovet, A.; Mattana, S.; Chin-Pampillo, J.; Otero, N.; Carrey, R.; Mondini, C.; Gascó, G.; Martí, E.; Margalef, R.; Alcañiz, J.M.; et al. Fresh biochar application provokes a reduction of nitrate which is unexplained by conventional mechanisms. Sci. Total Environ. 2021, 755, 142430. [CrossRef]

78. Uchida, Y.; Moriizumi, M.; Shimotsuma, M. Effects of rice husk biochar and soil moisture on the accumulation of organic and inorganic nitrogen and nitrous oxide emissions during the decomposition of hairy vetch (Vicia villosa) mulch. Soil Sci. Plant. Nutr. 2019, 65, 409-418. [CrossRef]

79. Libutti, A.; Cammerino, A.R.B.; Francavilla, M.; Monteleone, M. Soil Amendment with Biochar Affects Water Drainage and Nutrient Losses by Leaching: Experimental Evidence under Field-Grown Conditions. Agronomy 2019, 9, 758. [CrossRef]

80. Feng, Y.; Sun, H.; Xue, L.; Wang, Y.; Yang, L.; Shi, W.; Xing, B. Sawdust biochar application to rice paddy field: Reduced nitrogen loss in floodwater accompanied with increased NH3 volatilization. Environ. Sci. Pollut. Res. 2018, 25, 8388-8395. [CrossRef]

81. Wang, Y.; O'Connor, D.; Shen, Z.; Lo, I.M.C.; Tsang, D.C.W.; Pehkonen, S.; Pu, S.; Hou, D. Green synthesis of nanoparticles for the remediation of contaminated waters and soils: Constituents, synthesizing methods, and influencing factors. J. Clean. Prod. 2019, 226, 540-549. [CrossRef]

82. Jin, X.; Yu, B.; Lin, J.; Chen, Z. Integration of biodegradation and nano-oxidation for removal of PAHs from aqueous solution. ACS Sustain. Chem. Eng. 2016, 4, 4717-4723. [CrossRef]

83. Wu, J.; Yin, Y.; Wang, J. Hydrogen-based membrane biofilm reactors for nitrate removal from water and wastewater. Int. J. Hydrogen Energy 2018, 43, 1-15. [CrossRef]

84. Siciliano, A. Use of nanoscale zero-valent iron (NZVI) particles for chemical denitrification under different operating conditions. Metals 2015, 5, 1507-1519. [CrossRef] 
85. Shen, Z.; Wang, J. Biological denitrification using cross-linked starch/PCL blends as solid carbon source and biofilm carrier. Bioresour. Technol. 2011, 102, 8835-8838. [CrossRef]

86. Zhao, W.; Zhu, X.; Wang, Y.; Ai, Z.; Zhao, D. Catalytic reduction of aqueous nitrates by metal supported catalysts on Al particles. Chem. Eng. J. 2014, 254, 410-417. [CrossRef]

87. Ramavandi, B.; Mortazavi, S.B.; Moussavi, G.; Khoshgard, A.; Jahangiri, M. Experimental investigation of the chemical reduction of nitrate ion in aqueous solution by $\mathrm{Mg} / \mathrm{Cu}$ bimetallic particles. React. Kinet. Mech. Catal. 2011, 102, 313-329. [CrossRef]

88. Wang, Z.; Chen, C.; Liu, H.; Hrynshpan, D.; Savitskaya, T.; Chen, J.; Chen, J. Enhanced denitrification performance of Alcaligenes sp. TB by Pd stimulating to produce membrane adaptation mechanism coupled with nanoscale zero-valent iron. Sci. Total Environ. 2020, 708, 135063. [CrossRef]

89. Shen, Z.; Liu, D.; Dong, X.; Shi, J.; Ma, Y.; Fan, J.; Zhang, L. Nitrate Reduction Using Iron and Copper Bimetallic Nanoparticles Supported by Chelating Resin: Effect of Solution Chemistry, Mechanism, and Regeneration. J. Environ. Eng. 2020, 146, 04020011. [CrossRef]

90. Liu, Y.; Wang, J. Reduction of nitrate by zero valent iron (ZVI)-based materials: A review. Sci. Total Environ. 2019, 671, 388-403. [CrossRef]

91. Manikandan, V.; Jayanthi, P.; Priyadharsan, A.; Vijayaprathap, E.; Anbarasan, P.M.; Velmurugan, P. Green synthesis of pHresponsive $\mathrm{Al}_{2} \mathrm{O}_{3}$ nanoparticles: Application to rapid removal of nitrate ions with enhanced antibacterial activity. J. Photochem. Photobiol. A Chem. 2019, 371, 205-215. [CrossRef]

92. Zaki, S.A.; Eltarahony, M.M.; Abd-El-Haleem, D.A. Disinfection of water and wastewater by biosynthesized magnetite and zerovalent iron nanoparticles via NAP-NAR enzymes of Proteus mirabilis 10B. Environ. Sci. Pollut. Res. 2019, 26, 23661-23678. [CrossRef]

93. Pérez-Coronado, A.M.; Calvo, L.; Baeza, J.A.; Rodriguez, J.J.; Gilarranz, M.A. Control of selectivity in the reduction of nitrate by shielding of Pd-Cu/C catalysts with AOT. J. Ind. Eng. Chem. 2020, 82, 42-49. [CrossRef]

94. Jung, J.; Bae, S.; Lee, W. Nitrate reduction by maghemite supported Cu-Pd bimetallic catalyst. Appl. Catal. B Environ. 2012, 127, 148-158. [CrossRef]

95. Gao, J.; Jiang, B.; Ni, C.; Qi, Y.; Bi, X. Enhanced reduction of nitrate by noble metal-free electrocatalysis on P doped three-dimensional $\mathrm{Co}_{3} \mathrm{O}_{4}$ cathode: Mechanism exploration from both experimental and DFT studies. Chem. Eng. J. 2020, 382, 123034. [CrossRef]

96. Pandorf, M.; Pourzahedi, L.; Gilbertson, L.; Lowry, G.V.; Herckes, P.; Westerhoff, P. Graphite nanoparticle addition to fertilizers reduces nitrate leaching in growth of lettuce (Lactuca sativa). Environ. Sci. Nano 2020, 7, 127-138. [CrossRef]

97. Cordier, C.; Guyomard, K.; Stavrakakis, C.; Sauvade, P.; Coelho, F.; Moulin, P. Culture of Microalgae with Ultrafiltered Seawater: A Feasibility Study. SciMed. J. 2020, 2, 56-62. [CrossRef]

98. Volokita, M.; Belkin, S.; Abeliovich, A.; Soares, M.I.M. Biological denitrification of drinking water using newspaper. Water Res. 1996, 30, 965-971. [CrossRef]

99. Gibert, O.; Pomierny, S.; Rowe, I.; Kalin, R.M. Selection of organic substrates as potential reactive materials for use in a denitrification permeable reactive barrier (PRB). Bioresour. Technol. 2008, 99, 7587-7596. [CrossRef] [PubMed]

100. Mittal, A.; Singh, R.; Chakma, S.; Goel, G. Permeable reactive barrier technology for the remediation of groundwater contaminated with nitrate and phosphate resulted from pit-toilet leachate. J. Water Process. Eng. 2020, 37, 101471. [CrossRef]

101. Liu, Y.; Liu, Y.; Ma, L.; Gong, Y.; Qian, J. Corncob PRB for on-site nitrate removal in groundwater. Arab. J. Geosci. 2020, 13, 1-11. [CrossRef]

102. Graffam, M.; Paulsen, R.; Volkenborn, N. Hydro-biogeochemical processes and nitrogen removal potential of a tidally influenced permeable reactive barrier behind a perforated marine bulkhead. Ecol. Eng. 2020, 155, 105933. [CrossRef]

103. Özkaraova, E.B.; Kalin, R.M.; Gkiouzepas, S.; Knapp, C.W. Industrial and agricultural wastes as a potential biofilter media fogroundwater nitrate remediation. Desalin. Water Treat. 2019, 172, 330-343. [CrossRef]

104. Suhogusoff, A.V.; Hirata, R.; Aravena, R.; Robertson, W.D.; Ferrari, L.C.K.M.; Stimson, J.; Blowes, D.W. Dynamics of nitrate degradation along an alternative latrine improved by a sawdust permeable reactive barrier (PRB) installed in an irregular settlement in the municipality of São Paulo (Brazil). Ecol. Eng. 2019, 138, 310-322. [CrossRef]

105. Gibert, O.; Assal, A.; Devlin, H.; Elliot, T.; Kalin, R.M. Performance of a field-scale biological permeable reactive barrier for in-situ remediation of nitrate-contaminated groundwater. Sci. Total Environ. 2019, 659, 211-220. [CrossRef]

106. Gorski, G.; Fisher, A.T.; Beganskas, S.; Weir, W.B.; Redford, K.; Schmidt, C.; Saltikov, C. Field and Laboratory Studies Linking Hydrologic, Geochemical, and Microbiological Processes and Enhanced Denitrification during Infiltration for Managed Recharge. Environ. Sci. Technol. 2019, 53, 9491-9501. [CrossRef]

107. Guan, Q.; Li, F.; Chen, X.; Tian, C.; Liu, C.; Liu, D. Assessment of the use of a zero-valent iron permeable reactive barrier for nitrate removal from groundwater in the alluvial plain of the Dagu River, China. Environ. Earth Sci. 2019, 78, 244. [CrossRef]

108. Grau-Martínez, A.; Torrentó, C.; Carrey, R.; Soler, A.; Otero, N. Isotopic evidence of nitrate degradation by a zero-valent iron permeable reactive barrier: Batch experiments and a field scale study. J. Hydrol. 2019, 570, 69-79. [CrossRef]

109. Ye, L.; Yu, G.; Zhou, S.; Zuo, S.; Fang, C. Denitrification of nitrate-contaminated groundwater in columns packed with PHBV and ceramsites for application as a permeable reactive barrier. Water Sci. Technol. Water Supply 2017, 17, 1241-1248. [CrossRef]

110. Council Directive. 91/676/EEC of 12 December 1991 concerning the protection of waters against pollution caused by nitrates from agricultural sources. Off. J. L 1991, 375, 12. 
111. Chen, J.; Gong, Y.; Wang, S.; Guan, B.; Balkovic, J.; Kraxner, F. To burn or retain crop residues on croplands? An integrated analysis of crop residue management in China. Sci. Total Environ. 2019, 662, 141-150. [CrossRef]

112. Available online: https: / / www.scopus.com/results/results.uri? src $=\mathrm{s} \& \mathrm{sot}=\mathrm{b} \& \mathrm{sdt}=\mathrm{b} \&$ origin=searchbasic\&rr $=\& \mathrm{sl}=40 \& \mathrm{~s}=(\mathrm{KE}$ Y(biochar)ANDKEY(nitrateleaching))\&searchterm1=biochar\&connector=AND\&searchterm2=nitrateleaching\&searchTerms= \&connectors=\&field1=KEY\&field2=KEY\&fields= (accessed on 29 April 2021).

113. Available online: https: / / www.scopus.com/results/results.uri?src=s\&sot=b\&sdt=b\&origin=searchbasic\&rr=\&sl=52\&s=(KE Y(greennanoparticles)ANDKEY(nitrateleaching))\&searchterm1=greennanoparticles\&connector=AND\&searchterm2=nitratele aching\&searchTerms=\&connectors=\&field1=KEY (accessed on 29 April 2021).

114. Available online: https:/ / www.scopus.com/results/results.uri?src=s\&sot=b\&sdt=b\&origin=searchbasic\&rr $=\& s l=60 \& s=(K E$ Y(permeablereactivebarriers)ANDKEY(nitrateleaching))\&searchterm1=permeablereactivebarriers\&connector=AND\&searchte rm2=nitrateleaching\&searchTerms=\&connec (accessed on 29 April 2021). 